\title{
THE METHOD FOR ANALYSIS OF THE USE AND DEVELOPMENT FORECASTING OF HISTORICAL VOLHYNIA TERRITORIES
}

\author{
Pavlo OSTAPENKO \\ Taras Shevchenko National University of Kyiv, Ukraine \\ ostapenkopavlo@gmail.com
}

\begin{abstract}
To date, method for analysis of the current socio-economic conditions and development forecasting, approved for the administrative-territorial units, has been used only in predicting the development of the Autonomous Republic of Crimea, administrative regions (oblasts), groups of administrative regions (oblasts), and also for development of planning development schemes of territories. The article proves that this technique may be applied to some other individual parts of the Ukrainian territory, e.g. historical-geographic territories.

The author for the first time applies the method for analysis and development forecasting for the historical-geographical territory of Volhynia. This technique may help provide longtime forecast of the development of historical Volhynia. Also, the article defines the boundaries of the historic Volhynia and its present spatial structure. Administrative districts (raions) have been typed by their level of development, which allowed to identify the existing problems of the regional development and to work out basic ideas for interventions to address them.
\end{abstract}

Key words: historical-geographical territory, region, forecasting, regional planning, city-planning documentation.

UDC: 911.3

\section{МЕТОДИКА АНАЛІЗУ СТАНУ ВИКОРИСТАННЯ ТА ПРОГНОЗУВАННЯ РОЗВИТКУ ТЕРИТОРІї ІСТОРИЧНОї ВОЛИНІ}

\author{
Павло ОСТАПЕНКО
}

Київський начіональний університет імені Тараса Шевченка, україна

ostapenkopavlo@gmail.com

\begin{abstract}
Анотація: До теперішнього часу, методика аналізу сучасного соціально-економічного стану та прогнозування його розвитку для адміністративно-територіальних одиниць застосовувалась лише при прогнозуванні розвитку території АР Крим, областей та груп районів, при розроблені схем планування розвитку територій. У статті доведено, що дана методика може застосовуватись до окремих частин території України. Такими частинами можуть виступати історико-географічні території.

У статті вперше висвітлено застосування методики аналізу стану та прогнозування розвитку історико-географічної території - історичної Волині. За допомогою цієї методики може здійснюватися прогнозування розвитку історичної Волині на далеку перспективу. Також, визначено межі історичної Волині, її сучасна територіальна структура. Здійснено типізацію районів за рівнем їх розвитку, що дозволило виявити існуючі в регіоні проблеми розвитку та створити підгрунтя для розробки заходів по їх вирішенню.
\end{abstract}

Ключові слова: історико-географічна територія, регіон, прогнозування розвитку, регіональне планування, містобудівна документація.

удк: 911.3

Постановка проблеми. Планування розвитку території в організаційно-правовому полі регламентується Державними будівельними нормами. Вони повністю визначають етапи та механізми розроблення та затвердження схем планування розвитку територій на державному та регіональному рівнях. Однак, в містобудуванні як науці, застосовується чимало суспільно-географічних методів та методик дослідження. До них можна віднести метод аналізу стану та прогнозування розвитку територій адміністративно-територіальних одиниць (областей, груп районів тощо). Зараз методика залишається вузько направленою, оскільки використовувалась лише в територіальному плануванні, при розробці Схем планування розвитку адміністративних областей України [5].

(C) П. Остапенко
Актуальність дослідження. Вперше дана методика застосовується для аналізу стану та прогнозування розвитку історико-географічної території - історичної Волині. Що дає змогу визначити ступінь цілісності розвитку адміністративних районів (територіальних таксонів), які входять до одного історико-географічного регіону та в минулому складали єдиний регіон iз своїми полюсами розвитку та периферією.

\section{Мета і завдання статті.}

Першим завданням дослідження було встановлення меж історичної Волині, оскільки територія історико-географічних областей в історичному часі постійно змінювалась. Необхідно було визначити межі території, за час існування якої в регіоні були сформовані основні економічні та соціально-культурні зв'язку, які б максимально об'єднували всі можливі території, які входили до 
складу історичної Волині. Для реалізації головної мети дослідження, згідно даної методики, необхідно було провести аналіз усіх показників, на основі яких проводиться аналіз та прогноз розвитку. Після цього, провести аналіз сучасного соціальноекономічного стану та перспектив його розвитку на прикладів території адміністративних районів, які складають історико-географічний регіон - історичну Волинь.

Об’єкт дослідження становить сукупність адміністративних районів об'єднаних в історикогеографічний регіон, де найнижчою таксономічною одиницею (таксоном) виступає адміністративний район, а не адміністративна область. Предметом дослідження являється система індикативних показників, які характеризують наявний потенціал та набутий ними рівень розвитку адміністративного району (таксону).

Аналіз останніх досліджень та публікацій. Тематика роботи є новою, оскільки до цього не зустрічалась серед суспільно-географічних наукових видань. Для визначення адміністративних меж історичної Волині використовувались роботи Волинського центру історичних та геофізичних досліджень [1].

Виклад основного матеріалу.

Визначення меж регіону. Оскільки, здійснення аналізу буде вперше проводитись для історикогеографічного регіону, одним із перших завдань дослідження було встановлення його меж. Адже, за великий історичний період існування цього регіону - його межі постійно змінювались. Було прийнято, провести методику аналізу стану та прогнозування розвитку тих адміністративних районів, які входили, в історичному минулому, до складу Волинської губернії в межах XIX - поч. ХХстоліть. Оскільки, в цей період на території Волині була сформована єдина повітово-волосна адміністративно-територіальна система, найбільшого розвитку мала система розселення, сфера соціально-побутового обслуговування населення (розвиток мережі навчальних закладів, лікарень, тощо), транспортна система регіону (будівництво залізниці) (рис. 1) [2].

опис методики. Для аналізу соціальноекономічного та містобудівного розвитку окремих територіальних таксонів запроваджена система індикативних показників, яка враховує особливості розвитку соціально-економічного комплексу регіону, а також наявність інформаційно-статистичної бази [3]. Загалом система показників складається із кількох блоків. Перший блок показників характеризує потенціал розвитку окремих територіальних таксонів. Другий - характеризує досягнутий рівень розвитку кожного територіального таксону. Індикативний показник розраховується шляхом порівняння значення середньодержавного показника до значення цього ж показника в районі:

індикативний показник $\left(\mathrm{I}_{\kappa}\right)=$ середньодержавний показник / районний показник
При цьому кількісні значення групуються у кожному випадку на три групи: високі, середні та низькі:

Високий індикативний показник району: Ik > 1,1; Середній індикативний показник району: $0,9<\mathrm{Ik}<1,1$; Низький індикативний показник району: $\mathrm{Ik}<0,9$.

Визначення територіальних таксонів. Для того, щоб здійснити аналіз сучасного соціальноекономічного стану та прогнозу розвитку для будьякого регіону, спочатку, необхідно виявити внутрішні диспропорції між окремими адміністративнотериторіальними одиницями, які входять до його складу, потім виділити окремі територіальні таксони, які представлені адміністративними районами (в окремих випадках вони об'єднують адміністративні райони та території, підпорядковані містам обласного значення) [3].

Перелік та структура територіальних таксонів областей України, які увійшли до складу історичної Волині, в межах яких здійснювався їх аналіз, наводиться в таблиці 1.

Cтатистичні дані. Перш за все, дана методика грунтується на використанні статистичних даних, які максимально характеризують потенціал кожного територіального таксону та набутий ним, на основі використання цього потенціалу, рівень розвитку. Всі статистичні дані були отримані із статистичних щорічників кожної області, територія якої, згідно проведених досліджень, входить до історичної Волині $[6 ; 7 ; 8 ; 9 ; 10]$.

Перейдемо до аналізу основних показників та проведення прогнозу (згідно методики).

Перший блок показників - потенціал розвитку окремих територіальних таксонів.

До нього входять ті показники, на основі яких можна визначити запаси продуктивних сил, природно-ресурсного потенціалу та територіального потенціалу, які можуть бути використані для забезпечення матеріальних потреб розвитку теритоpiї в майбутньому. До таких показників відносять:

1. Зручність транспортно-географічного положення.

2. Забезпеченість природно-ресурсним

потенціалом:

2.1 Мінеральні ресурси.

2.2 Водні ресурси.

2.3 Земельні ресурси.

2.4 Лісові ресурси.

2.5 Фауністичні ресурси.

2.6 Природно-рекреаційні ресурси.

3. Основні фонди.

4. Рівень розвитку транспортної мережі.

5. Трудовий потенціал.

Розглянемо склад кожного показника окремо.

Зручність транспортно-географічного положення окремого таксону розраховується на основі графової моделі за індексами зручності розташування таксонів. Спочатку розраховуються окремі індекси зручності, які характеризують розташування таксонів між собою (I); до обласного 


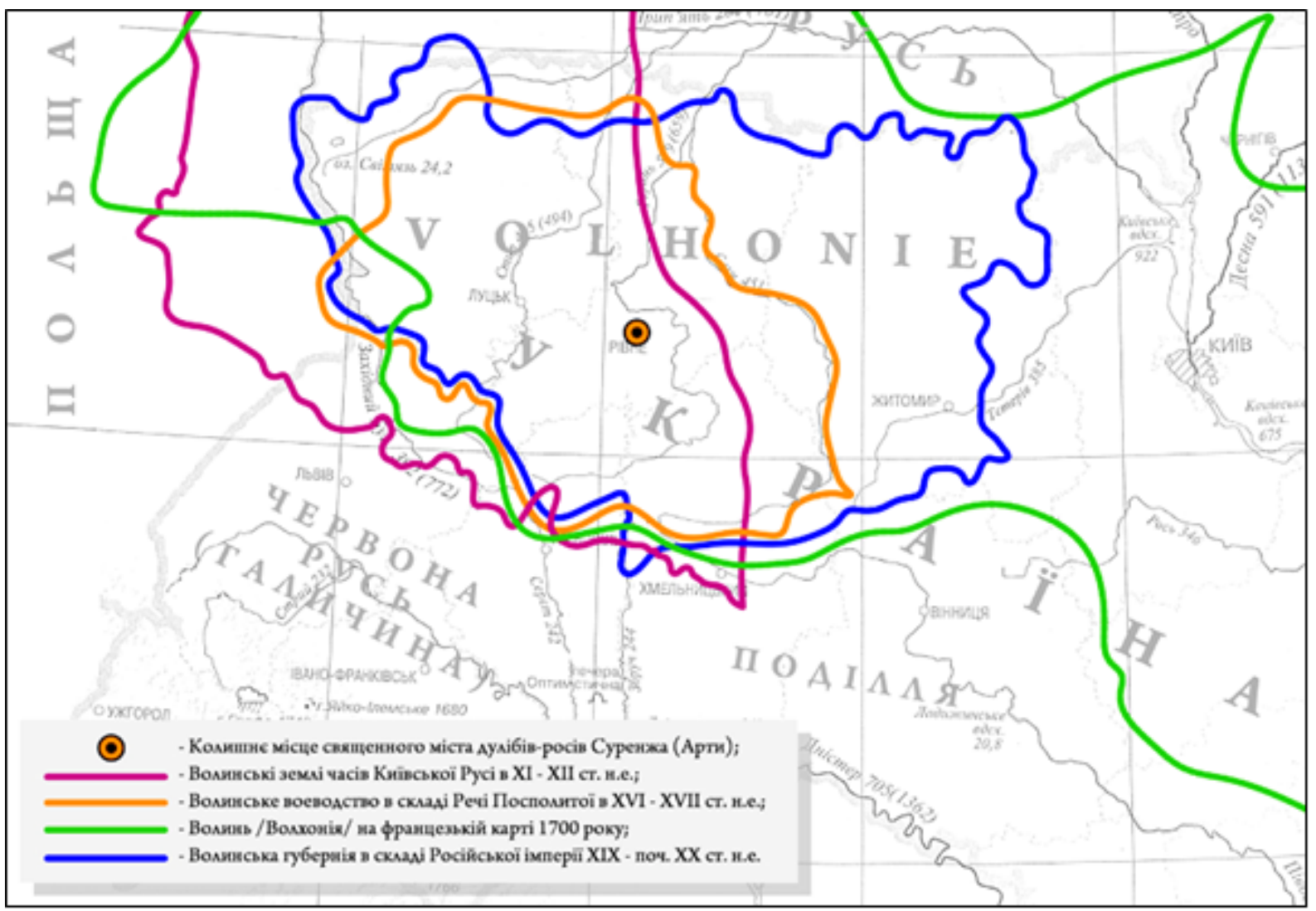

Рис.1. Карта Волинських земель в ІІ тис. н.е. [2]

Таблиияя 1

Характеристика території адміністративних районів, які входять до історичної Волині

\begin{tabular}{|c|c|c|c|c|c|}
\hline \multirow[b]{2}{*}{ Область } & \multirow{2}{*}{$\begin{array}{c}\text { Кількість } \\
\text { територіальних } \\
\text { таксонів } \\
\text { (адміністративних } \\
\text { районів) }\end{array}$} & \multicolumn{2}{|c|}{$\begin{array}{c}\text { Загальна плоша } \\
\text { таксонів }\end{array}$} & \multicolumn{2}{|c|}{$\begin{array}{l}\text { Загальна кількість } \\
\text { населення (2010 р.) }\end{array}$} \\
\hline & & muc. $\kappa M^{2}$ & $\%$ & тис. чол. & $\%$ \\
\hline Волинська & 16 & 20,14 & 27,7 & 1042,9 & 29,3 \\
\hline Рівненська & 16 & 20,05 & 27,6 & 1161,2 & 32,6 \\
\hline Житомирська & 16 & 22,29 & 30,7 & 839,7 & 23,6 \\
\hline Хмельницька & 8 & 8,35 & 11,5 & 416,7 & 11,7 \\
\hline Тернопільська & 2 & 1,76 & 2,4 & 103,5 & 2,9 \\
\hline Всього & 57 & 72,59 & 100 & 3564,1 & 100 \\
\hline
\end{tabular}

центру (I), до центрів сусідніх областей (I) та до найближчого транспортного переходу на кордоні (In). Комплексний індекс зручності (T) для кожного територіального таксону розраховується як середньозважена величина від значень чотирьох окремих індексів.

Зважування виконується на основі кореляційного аналізу. За допомогою кореляційного аналізу виявляться тіснота зв'язку двох (чи великого числа) ознак (показників) між собою. При парному зв'язку тіснота зв'язку виміряється насамперед кореляційним відношенням, що позначається $\mathrm{r}_{\mathrm{xy}}$ :

$\mathrm{r}_{\mathrm{xy}}=\sqrt{ }\left(\Sigma\left(\mathrm{x}_{\mathrm{i}}-\mathrm{x}_{\text {cep. }}\right) *\left(\mathrm{y}_{\mathrm{i}}-\mathrm{y}_{\text {cep. }}\right)\right) /\left(\mathrm{n} * \sqrt{ } \sigma_{\mathrm{x}}{ }^{2 *} \sigma_{\mathrm{y}}{ }^{2}\right)$,

де:

$\mathrm{x}_{\mathrm{i}}$ - i-e значення ознаки $\mathrm{x}$; $\mathrm{y}_{\mathrm{i}}$ - i-е значення ознаки y;

$\mathrm{x}_{\text {сер. }}$ - середнє значення ознаки $\mathrm{x}$;

$\mathrm{y}_{\text {сер. }}$ - середнє значення ознаки у;

n - кількість спостережень;

$\sigma_{\mathrm{x}}{ }^{2}-$ середньоквадратичне відхилення по ознаці

$\mathrm{x} \quad \sigma_{\mathrm{x}}^{2}=\left(\Sigma\left(\mathrm{x}_{\mathrm{i}}-\mathrm{x}_{\text {сер }}\right)^{2} / \mathrm{n}\right.$;

$\sigma_{\mathrm{y}}^{2}-$ середньоквадратичне відхилення по ознаці

$\mathrm{y}^{\mathrm{y}} \quad \sigma_{\mathrm{y}}{ }^{2}=\left(\Sigma\left(\mathrm{y}_{\mathrm{i}}-\mathrm{y}_{\mathrm{cp}}\right)^{2 / n}\right.$;

Основою виміру зв'язків багатофакторної системи $є$ матриця парних коефіцієнтів кореляції. Квадрат кореляційного відношення називається коефіцієнтом детермінації $\mathrm{r}^{2}$. У результаті впливу ознак виникає емпірична результуюча ознака. Коефіцієнт детермінації інтерпретується як частка загальної дисперсії результуючої ознаки, що 
пояснюється варіацією k-ої ознаки-фактора.

Багатомірні показники структури результуючої ознаки можна отримати трьома способами. Перший - за допомогою простої арифметичної середньої величини часткою. Очевидно, при цьому вважаємо всі ознаки структури рівноправними, що, звичайно, є спрощенням реальності. Другий спосіб складається в обчисленні зважених середніх часток. При цьому вагами служать експертні оцінки порівняльної важливості ознак. Третій спосіб побудови багатомірних середніх часток не вимагає залучення яких-небудь суб'єктивних експертних оцінок - використовується тільки інформація, що міститься у вихідних частках. Більш інформативною, а отже, вагомою, визнається та ознака, що має більш високий коефіцієнт детермінації зі всіма ознаками, що залишаються. Обчислимо попарні i середні коефіцієнти детермінації, а потім нормалізуємо їх на суму середніх коефіцієнтів.

Наприклад, матриця коефіцієнтів кореляції для блоку ознак «Зручність транспортно-географічного положення» становитиме:

\begin{tabular}{|l|c|c|c|c|}
\hline & Iт & Io & Ic & II \\
\hline Iт & $\mathbf{1 , 0 0 0}$ & $\mathbf{0 , 4 7 6}$ & $\mathbf{- 0 , 1 0 4}$ & $\mathbf{0 , 3 5 5}$ \\
\hline Іо & 0,476 & 1,000 & $-0,343$ & 0,366 \\
\hline Іс & $-0,104$ & $-0,343$ & 1,000 & $-0,343$ \\
\hline Іп & 0,355 & 0,366 & $-0,343$ & 1,000 \\
\hline
\end{tabular}

Матриця коефіцієнтів детермінації у свою чергу становитиме:

\begin{tabular}{|l|c|c|c|c|}
\hline & IT & Io & Ic & II \\
\hline Iт & 1,000 & 0,227 & 0,011 & 0,126 \\
\hline Іо & 0,227 & 1,000 & 0,118 & 0,134 \\
\hline Іс & 0,011 & 0,118 & 1,000 & 0,118 \\
\hline Іп & 0,126 & 0,134 & 0,118 & 1,000 \\
\hline
\end{tabular}

Середні коефіцієнти детермінації складають:

$$
\begin{array}{llll}
0,341 & 0,370 & 0,312 \quad 0,344
\end{array}
$$

Нормалізуємо їх на суму середніх коефіцієнтів детермінації 1,366 та отримаємо ваги ознак для:

$$
\begin{array}{cccc}
\text { IT } & \text { Io } & \text { Ic } & \text { III } \\
0,25 & 0,27 & 0,23 & 0,25
\end{array}
$$

В результаті розрахунків отримані значення індексів для кожного 3 територіальних таксонів регіону показані на карті нижче.

\section{Забезпеченість} природно-ресурсним потенціалом окремого таксону (П комп. $)$ розраховується у вигляді індексу, нормованого до середньодержавного показника. Розрахунок індексу природно-ресурсного потенціалу здійснюється за формулою:

$$
\begin{aligned}
& \text { Пкомп.і = Пмі/Пму + Пві/ Пву + Пзі/ Пзу + } \\
& + \text { Плі/Плу + Пфі/Пфу + Прі/ Пру, }
\end{aligned}
$$

де $\Pi_{\text {мі }}, \Pi_{\text {ві }}, \Pi_{\text {зі }}, \Pi_{л і}, \Pi_{\phi і}, \Pi_{\text {рі }}-$ вартість відповідно: мінеральних, водних, земельних, лісових, фауністичних тп рекреаційних ресурсів і-го таксону у грн. на 1 га його площі; $\Pi_{\text {му }}, \Pi_{\text {ву }}, \Pi_{\text {зу }}, \Pi_{л у}, \Pi_{\phi у}, \Pi_{\text {ру }}$ - середньоукраїнська вартість відповідно: мінеральних, водних, земельних, лісових, фауністичних та рекреаційних ресурсів і у грн. на га.

Показники вартості природно-ресурсного потенціалу та його структури у районах області були розраховані на основі вихідних даних та методики запропонованої професором В. П. Руденком [4].

В результаті проведеного аналізу отримані значення потенціалу для кожного $з$ таксонів регіону показані на карті нижче.

Виробничий потенціал (основні фонди). Забезпеченість територіальних таксонів основними фондами (Ф) оцінюється за забезпеченістю основними фондами на одного жителя (Ф1) нормованих до середньодержавного показника.

Рівень розвитку транспортної мережі визначається через індекс, що являє собою співвідношення щільності автомобільних (ТM1) та залізничних (ТМ2) транспортних магістралей територіального таксону до відповідного середньодержавного показника. Значення даного індексу відображає потенційні можливості кожного таксону в транспортному обслуговуванні населених пунктів, промисловості, сільського господарства, рекреаційної сфери через зменшення витрат на транспортні перевезення, інтермодальне сполучення. Значення індексу розвитку транспортної мережі (TM) для окремих таксонів регіону показані на карті нижче.

Tрудовий потенціал кожного 3 виділених територіальних таксонів визначається за допомогою індексу розвитку трудового потенціалу (ТП), який, в свою чергу, розраховується на основі індикативних показників демографічного навантаження ТП до працюючого) та рівня освіти населення ТП нормованих до середньодержавних показників.

Визначення загального індексу потенціалу розвитку кожного територіального таксону проводиться на основі отримання середньозваженого показника. Зважування виконується на основі кореляційного аналізу.

Отже, перший блок показників дозволив визначити ступінь потенціалу для розвитку кожного територіального таксону (адміністративного району) на теперішній період та в майбутньому (на певний розрахунковий період).

3 Рис. 2 видно, що високий потенціал мають територіальні таксони, які зосереджені навколо обласних центрів. Переважна більшість районів центру мають середній потенціал для розвитку. В таких таксонах знаходяться великі промислові підприємства, краще розвинена соціальна інфраструктура. Можна припустити, що територіальні таксони 3 високим та середнім потенціалом для розвитку формують так звану центральну планувальну вісь регіону. Низький потенціал для розвитку мають територіальні таксони периферії 
півдня та півночі регіону - таксони, що найбільше віддалені від центральної планувальної осі.

Другий блок показників, який використовусться в методиці, характеризує досягнутий рівень розвитку кожного територіального таксону (адміністративного району). До нього входять показники, на основі яких можна визначити рівень економічного, соціального, екологічного та містобудівного розвитку.

Цей блок включає наступні показники:

1. Рівень розвитку соціальної інфраструктури.

2. Рівень соціального розвитку.

3. Рівень економічного розвитку.

4. Стан навколишнього середовища.

5. Рівень містобудівний розвитку.

Так само, як i потенціал кожного таксону, рівень розвитку кожного територіального таксону визначається на основі визначення індикативного показника, який визначається шляхом порівняння значення певного показниками по конкретному таксону до значення цього ж показникам в цілому по країні.

Рівень розвитку соціальної інфраструктури розраховується на основі даних по ознакам «житлова забезпеченість загальною площею житла», «будівництво житла на рік на одного жителя», «забезпеченість лікарнями на 1000 жителів», «забезпеченість амбулаторно-поліклінічними закладами на 1000 жителів», «роздрібний товарообіг на душу населення».

Зважування виконується на основі кореляційного аналізу. За допомогою кореляційного аналізу виявляться тіснота зв'язку двох (чи великого числа) ознак (показників) між собою. При парному зв'язку тіснота зв'язку виміряється насамперед кореляційним відношенням, що позначається $\mathrm{r}_{\mathrm{xy}}$ :

$$
\mathrm{r}_{\mathrm{xy}}=\sqrt{ }\left(\Sigma\left(\mathrm{x}_{\mathrm{i}}-\mathrm{x}_{\text {cep. }}\right) *\left(\mathrm{y}_{\mathrm{i}}-\mathrm{y}_{\text {cep. }}\right)\right) /\left(\mathrm{n} * \sqrt{ } \sigma_{\mathrm{x}}{ }^{2 *} \sigma_{\mathrm{y}}{ }^{2}\right),
$$

де:

$\mathrm{x}_{\mathrm{i}}$ - i-e значення ознаки $\mathrm{x}$;

$\mathrm{y}_{\mathrm{i}}$ - i-е значення ознаки y;

$\mathrm{x}_{\text {cep. }}$ - середнє значення ознаки $\mathrm{x}$;

$\mathrm{y}_{\text {cep. }}$ - середнє значення ознаки у;

$\mathrm{n}$ - кількість спостережень;

$\sigma_{\mathrm{x}}{ }^{2}-$ середньоквадратичне відхилення по ознаці

$\mathrm{x} \quad \sigma_{\mathrm{x}}^{2}=\left(\Sigma\left(\mathrm{x}_{\mathrm{i}}-\mathrm{x}_{\text {сер. }}\right)^{2 / n}\right.$;

$\sigma_{\mathrm{y}}^{2}-$ середньоквадратичне відхилення по ознаці

$\mathrm{y} \quad \sigma_{\mathrm{y}}^{2}=\left(\Sigma\left(\mathrm{y}_{\mathrm{i}}-\mathrm{y}_{\mathrm{cp}}\right)^{2 / \mathrm{n}}\right.$;

Основою виміру зв'язків багатофакторної системи є матриця парних коефіцієнтів кореляції. Квадрат кореляційного відношення називається коефіцієнтом детермінації $\mathrm{r}^{2}$. У результаті впливу ознак виникає емпіричний результуюча ознака. Коефіцієнт детермінації інтерпретується як частка загальної дисперсії результуючої ознаки, що пояснюється варіацією k-ої ознаки-фактора.

Багатомірні показники структури результуючої ознаки можна отримати трьома способами. Перший - за допомогою простої арифметичної середньої величини. Очевидно, при цьому вважаємо всі ознаки структури рівноправними, що, звичайно, $є$ спрощенням реальності. Другий спосіб складається в обчисленні зважених середніх часток. При цьому вагами служать експертні оцінки порівняльної важливості ознак. Третій спосіб побудови багатомірних середніх часток не вимагає залучення яких-небудь суб'єктивних експертних оцінок використовується тільки інформація, що міститься у вихідних частках. Більш інформативним, а отже, вагомим визнається та ознака, що має більш високий коефіцієнт детермінації з всіма ознаками, що залишаються. Обчислимо попарні i середні коефіцієнти детермінації, а потім нормалізуємо їх на суму середніх коефіцієнтів.

Наприклад, матриця коефіцієнтів кореляції для блоку ознак «Рівень розвитку соціальної інфраструктури» становитиме:

\begin{tabular}{|l|l|l|l|l|l|}
\hline & CI 1 & CI 2 & CI 3 & CI 4 & CI 5 \\
\hline CI 1 & 1,00 & 0,07 & $-0,56$ & $-0,10$ & $-0,58$ \\
\hline CI 2 & 0,07 & 1,00 & 0,09 & $-0,36$ & 0,23 \\
\hline CI 3 & $-0,56$ & 0,09 & 1,00 & 0,29 & 0,33 \\
\hline CI 4 & $-0,10$ & $-0,36$ & 0,29 & 1,00 & $-0,30$ \\
\hline CI 5 & $-0,58$ & 0,23 & 0,33 & $-0,30$ & 1,00 \\
\hline
\end{tabular}

Матриця коефіцієнтів детермінації у свою чергу становитиме:

\begin{tabular}{|l|c|c|c|c|}
\hline & CI 1 & CI 2 & CI 3 & CI 4 \\
\hline CI 1 & & 0,01 & 0,31 & 0,01 \\
\hline CI 2 & 0,01 & & 0,01 & 0,13 \\
\hline CI 3 & 0,31 & 0,01 & & 0,08 \\
\hline CI 4 & 0,01 & 0,13 & 0,08 & \\
\hline CI 5 & 0,33 & 0,05 & 0,11 & 0,09 \\
\hline
\end{tabular}

Середні коефіцієнти детермінації складають:

\begin{tabular}{|l|l|l|l|l|}
\hline & 0,16 & 0,05 & 0,13 & 0,08 \\
\hline
\end{tabular}

Нормалізуємо їх на суму середніх коефіцієнтів детермінації 0,56 та отримаємо ваги ознак для:

\begin{tabular}{|l|l|l|l|l|}
\hline CI 1 & CI 2 & CI 3 & CI 4 & CI 5 \\
\hline 0,29 & 0,09 & 0,23 & 0,14 & 0,33 \\
\hline
\end{tabular}

В результаті розрахунків отримані наступні значення показників для кожного з таксонів показані на карті нижче.

Якість соціального розвитку. Для аналізу рівня соціального розвитку використовувались індекси, які відображають народжуваність за рік, коефіцієнт народжуваності на 100 жителів, смертність за рік, коефіцієнт смертності на 100 жителів, природний приріст за рік, коефіцієнт природного приросту на 100 жителів, дитяча смертність на 1000 дітей, середньомісячна заробітна плата, рівень безробіття.

Карта розподілу показників якості соціального розвитку у розрізі територіальних таксонів дається у додатку.

Рівень економічного розвитку. Рівень економічного розвитку територіальних таксонів (Е) оцінюється за наступними показниками: обсяги реалізованої продукції промисловості на одного мешканця (E1); продукція сільського господарства на 1 га (E2); обсяг інвестицій на одного мешканця, нормованих до середньодержавного показника (E3). 


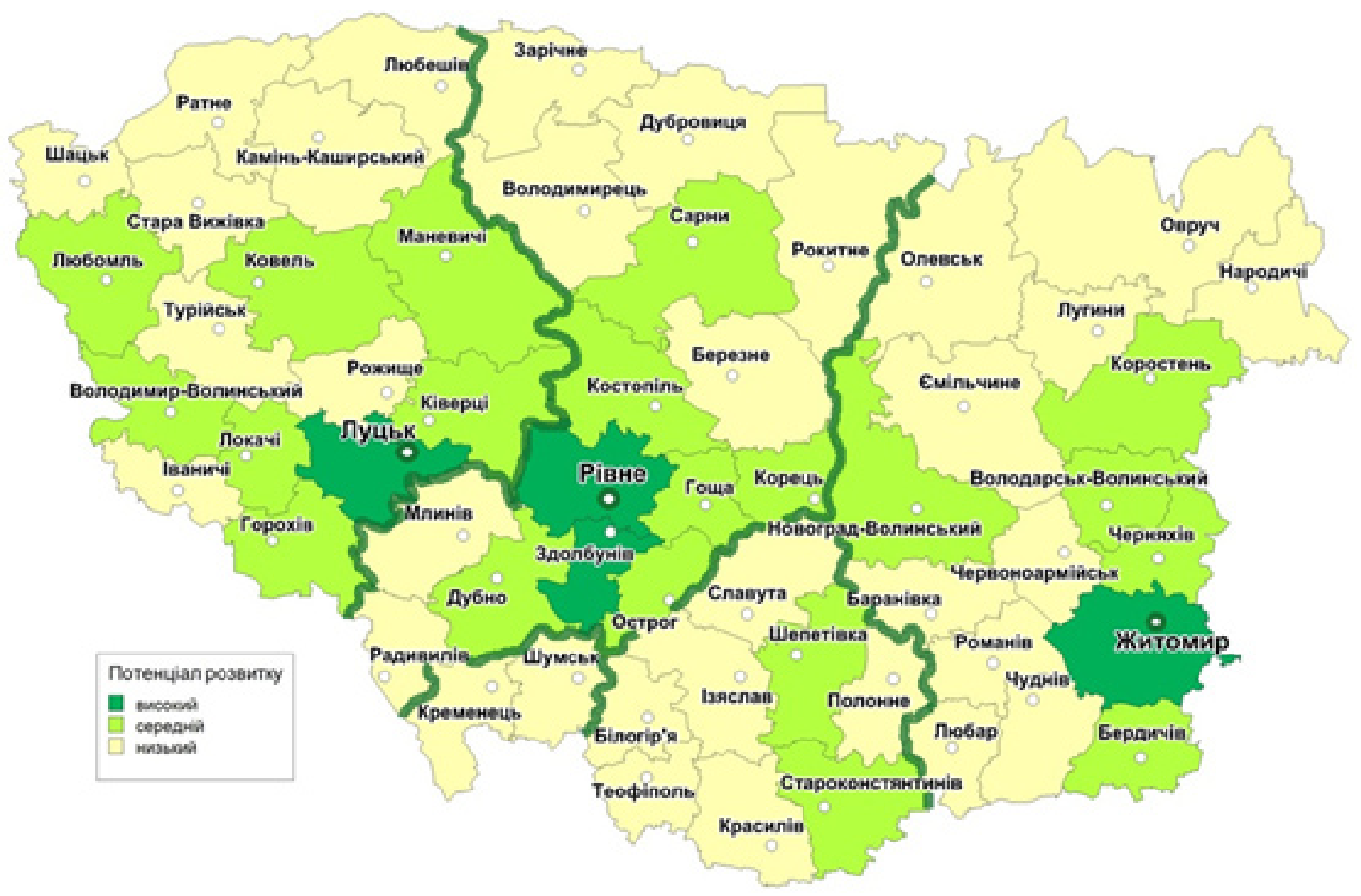

Рис.2. Потенціал розвитку територіальних таксонів історичної Волині

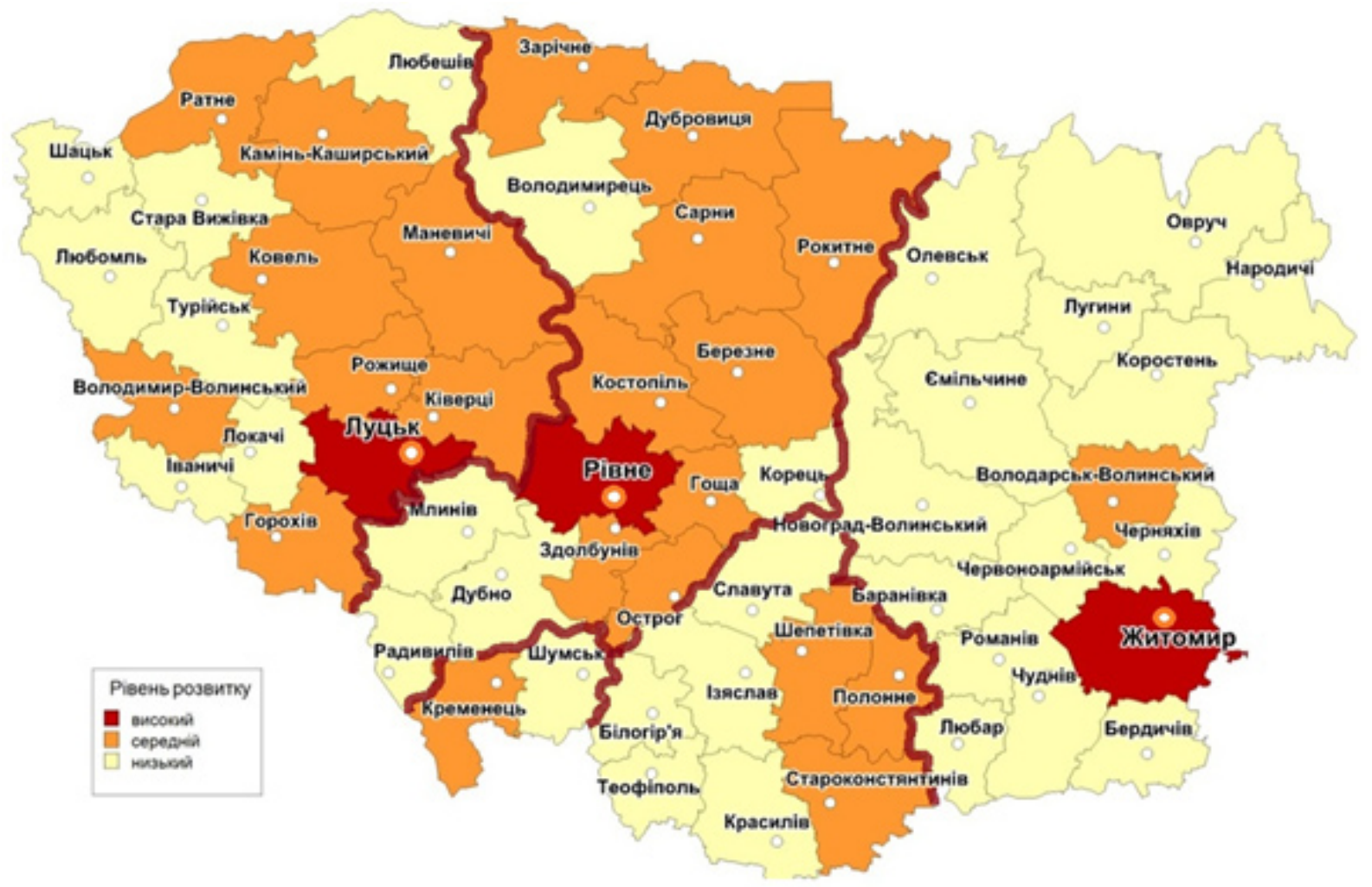

Рис.3. Рівень розвитку територіальних таксонів історичної Волині 
Стан навколиинього середовища. СТан навколишнього середовища визначається показниками обсягів викидів шкідливих речовин у повітря від стаціонарних i мобільних джерел (EК1) та обсягів накопичення твердих відходів виробництва на одного жителя (ЕК2). Показник стану навколишнього середовища таксону (ЕК) одержується як обернена середньозважена величина, що нормується до середньодержавного значення.

Містобудівний розвиток. Для аналізу рівня містобудівного розвитку вибрані показники, які характеризують щільність забудови (M1), рівень урбанізації (M2) та щільність населення (M3) i стандартизовані до середньодержавного показника. Індекс рівня містобудівного розвитку (М), розрахований як середньозважена величина.

Визначення загального індексу рівня розвитку кожного територіального таксону проводиться аналогічно попередньому індексу загального потенціалу - на основі отримання середньозваженого показника. Зважування виконується на основі кореляційного аналізу.

Отже, другий блок показників визначив рівень розвитку кожного територіального таксону, використовуючи той потенціал розвитку, який зосереджений на його території. потенціалу для розвитку кожного територіального таксону (адміністративного району) на теперішній період та в майбутньому (на певний проміжок часу).

Найвищі показники рівня розвитку, так само як і для його потенціалу, мають територіальні таксони, які зосереджені навколо обласних центрів. Близько третини таксонів мають середні рівень розвитку. Це в переважній більшості територіальні таксони центру та півночі Волинської та Рівненської областей. Низький рівень розвитку мають таксони в Житомирській, Тернопільській, частково Хмельницькій областях, на півдня та заходу Волинської області, півдня Рівненської.

Для того, щоб здійснити комплексний аналіз стану та прогнозу розвитку кожного територіального таксону та регіону в цілому, необхідно: порівняти загальний індекс потенціалу кожного таксону та загальний індекс рівня розвитку кожного таксону. Такий комплексний аналіз двох блоків показників забезпечує виявлення існуючих в області проблем розвитку та дозволяє створити підгрунтя для розробки заходів по їх вирішенню. Проведений аналіз потенціалу та рівня соціально-економічного розвитку окремих територіальних таксонів історичної Волині дозволяє виділити 6 їх типів (Рис. 4):

1 тип. Таксони з низьким потенціалом та рівнем розвитку. До цього типу входять райони півночі та півдня Житомирської області, північно-західної частини Хмельницької та деякі райони півночі Волинської області. Ці таксони мають найнижчий потенціал та рівень розвитку, на їх території доцільно розвивати підтримуючі галузі господарства для аграрних регіонів та підвищувати рівень містобудівного та соціального розвитку.

2 тип. Таксони 3 низьким потенціалом та середнім рівнем розвитку. До цього типу входять райони півночі Волинської та Рівненської області. Дані таксони

3 тип. Таксони із середнім потенціалом та низьким рівнем розвитку. Це райони центральної частини Житомирської області та деякі райони Рівненської та Волинської області. Маючи середній потенціал для розвитку господарства та соціальної сфери рівень розвитку цих районів є низьким. Саме

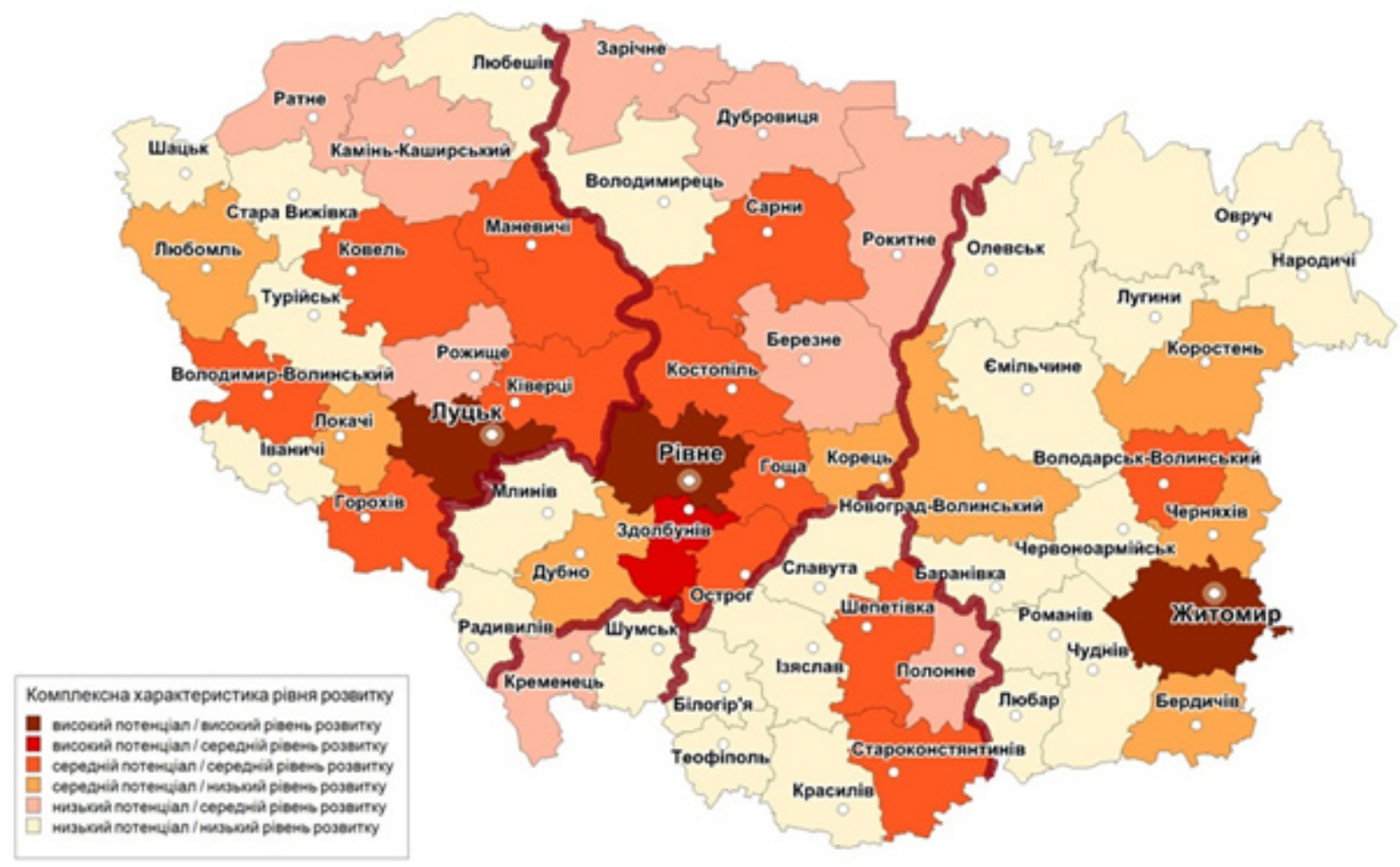

Рис.4. Комплексна характеристика потенціалу та рівня розвитку територіальних таксонів історичної Волині 
на розвиток цих районів повинна бути направлена майбутня програма розвитку області чи регіону.

4 тип. Таксони із середнім потенціалом та середнім рівнем розвитку. До цього типу відносяться райони центру Волинської та Рівненської областей, північно-східної частини Хмельницької області. Як видно із картограми, разом із таксонами 5-го і 6-го типу даний тип таксонів формує ядро розвитку регіону.

5 тип. Таксони 3 високим потенціалом та середнім рівнем розвитку. До цього типу відноситься лише один район Рівненської-Здолбунівський. Район входить в Рівненську міську агломерацією, саме на цей район повинна бути сконцентрована основна увага в стратегії розвитку області та регіону.

6 тип. Таксони із високим потенціалом та рівнем розвитку. До цього типу, на території Волині, входять лише райони обласних центрів Волині. Всі таксони мають в своєму складі міста обласного підпорядкування, є найбільшими за населенням i найбільш економічно розвинуті, завдяки концентрації основних підприємств області, трудового потенціалу, хорошого географічного розташування. Ці райони (Луцький та Рівненський райони) виступають як центроформуючі Волинського регіону в цілому, навколо них сконцентровані таксони (адміністративні райони) 3-го та 4-го типу, які мають потенціал для подальшого розвитку регіону.

\section{Висновки.}

Завдяки методиці було визначено рівень розвитку кожного територіального таксону (адміністративного району), які входять до історикогеографічного регіону Волинь.

Головною метою даної методи $є$ визначення стану розвитку кожного територіального таксону, для подальшого вирівнювання значних розбіжностей у соціально-економічних та екологічних характеристик окремих таксонів та розроблення рекомендацій (прогнозу), щодо перспективного розвитку кожного їх типів, пропозиції щодо раціонального використання їх територіальних ресурсів.

Завдяки проведеному аналізу було визначено ядро сучасного розвитку регіону. Це райони центральної частини Волинського регіону Рівненський та Луцький. Навколо районів обласних центрів сконцентровані райони із середнім потенціалом та середнім, чи низьким рівнем розвитку. Разом вони формують ядро розвитку регіону. Згідно даного дослідження, територіальні таксонів інших областей (Тернопільської, Хмельницької, Житомирської), що історично входять в склад Волинського регіону, в переважній більшості, через периферійність свого розташування відносно ядра регіону та через низький потенціал для подальшого розвитку, не можуть бути планувальними ядрами Волинського регіону.

«Місія» Волинського регіону, в майбутньому, має бути визначена в результаті співставлення сприятливих умов та потенціальних можливостей розвитку тих територіальних таксонів, які можуть гальмувати подальший розвиток регіону в цілому.

\section{References:}

1. Dem'âmov V.O. Karti ros'kih zemel' pìzn'ogo seredn'oviččâ: Volin'-Ukraïna 16-17st.n.e. [Maps of the Ros Lands in the the late middle ages: Volhynia and Ukraine in XVI-XVII c.] Volhynian Center for Historical and Geophysical Research. Access mode: http://rivne-surenzh.com.ua/ua/our_articles/123 (In Ukrainian).

2. Dem'âmov V.O., Andrêêv O.A. Karta. Volin' v İ̀ tis. n.e. [Map. Volhynia in the Second Millennium]. Access mode: http://rivne-surenzh.com.ua/ua/additional/maps/46 (In Ukrainian).

3. Metodičnì rekomendacii dlâ provedennâ praktičnih zanât' z lekcìjnogo kursu «Menedžment u mìstobuduvannì» [Guidelines for practical sessions for the lecture course "Management in city planning"]. Ed.: Û. M. Paleha. Kyiv, 2006, 27 p. (In Ukrainian).

4. Rudenko V.P. Geografiâ prirodno-resursnogo potencìalu Ukraïni [Geography of natural-resource potential of Ukraine]. Chernivtsi, 2010, pp. 255-277. (In Ukrainian).

5. State Building Rules Б.1.1-13:2012 Sklad ì zmìst mìstobudìvnoï dokumentaciï na deržavnomu ta regìonal'nomu rìvnâh [Composition and content of construction state and regional documents]. Куіv, Мінрегіон України, 2012. (In Ukrainian).

6. Statističnij ŝoričnik Hmel'nic'koï oblastì za 2010 rìk [Statistical Yearbook of Khmelnytskyi Region in 2010]. Ed.: V. V. Skal's'kij. Main Statistics Department in Khmelnytskyi Region, Khmelnytskyi, 2011. - 433 c. (In Ukrainian).

7. Statističnij ŝorì̌nik Rìvnens'koï oblastì za 2010 rìk [Statistical Yearbook of Rivne Region in 2010]. Ed.: Û.V. Moroz. Main Statistics Department in Rivne Region, Rivne, 2011, 489 p. (In Ukrainian).

8. Statističnij ŝoričnik Ternopil's'koï oblastì za 2010 rìk [Statistical Yearbook of Ternopil Region in 2010]. Ed.: V.G. Kirič. Main Statistics Department in Ternopil Region, Ternopil, 2011, 457 p. (In Ukrainian).

9. Statističnij ŝorì̌nik Volins'koï oblastì za 2010 rìk [Statistical Yearbook of Volhynia Region in 2010]. Ed.: M. Ì. Motil'. Main Statistics Department in Volhynia Region, Lutsk, 2011, 572 p. (In Ukrainian).

10. Statističnij ŝoričnik Žitomirs'koï oblastì za 2010 rìk [Statistical Yearbook of Zhytomyr Region in 2010]. Ed.: G.A. Pašins'ka. Main Statistics Department in Zhytomyr Region, Zhytomyr, 2011, 467 p. (In Ukrainian). 